
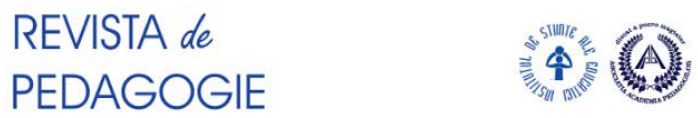

http://revped.ise.ro

Print ISSN 0034-8678; Online ISSN: 2559 - 639X

\title{
BULLYING IN SCHOOL - PREVENTION AND INTERVENTION STRATEGIES
}

\author{
BULLYINGUL ÎN ȘCOALĂ - STRATEGII DE PREVENȚIE ȘI INTERVENȚIE
}

\section{Luminița Mihaela DRĂGHICESCU, Ioana STĂNCESCU}

$$
\text { Journal of Pedagogy, } 2019 \text { (2), } 107 \text { - } 124
$$

https://doi.org/10.26755/RevPed/2019.2/107

The online version of this article can be found at: http://revped.ise.ro/category/2019-en/

\section{(c) (1) (3)}

This work is licensed under the Creative Commons Attribution-NonCommercial-ShareAlike 4.0 International License. View, CA 94042, USA.

Published by:

\section{INSTITUTUL DE ȘTIINȚE ALE EDUCAȚIEI}

http://www.ise.ro/

Further information about Revista de Pedagogie - Journal of Pedagogy can be found at:

Editorial Policy: http://revped.ise.ro/editorial-policy/

Author Guidelines: http://revped.ise.ro/the-writer-guide-2/ 


\title{
BULLYING IN SCHOOL - PREVENTION AND INTERVENTION STRATEGIES
}

\section{Lumini a Mihaela Drăghicescu* Ioana Stăncescu**}

\author{
Valahia University of Târgovişte, \\ DPPD, \\ Târgovişte, Romania \\ lumidraghicescu@yahoo.com,stancescu_ioana@yahoo.com
}

\begin{abstract}
In a world that seems to lose its axiological landmarks, in which conflicts and aggressiveness are present at any level of society, in various forms, the school is no longer a safe and positive environment for either children or teachers. Bullying is a phenomenon that is implied into school life, having negative effects on the physical and mental health of children, on their personality, as well as on the quality of the educational process.

In this context, through our study, we intend to investigate the extent to which teachers, being aware of the seriousness of the actions subsumed by bullying, are intervening promptly, adopting a series of strategies to prevent and/or combat this phenomenon. At the level of the European Union and beyond, there is an obvious concern for preventing and limiting the school bullying. Consequently, through our investigative approach, in which we included a group of teachers from pre-university education, we also aim to identify the extent to which they are aware of the need for involvement, in order to promote a safe educational climate, to ensure the physical and emotional security of their students.

The results of our research revealed a proactive attitude on behalf of the teachers, who were aware of the importance of their intervention for the development of harmonious relationships among students, for the training/development of their socio-emotional competences, as well as for diminishing/stopping bullying, through mediation, appropriate sanctions, effective collaboration with all the educational partners.
\end{abstract}

* Senior Lecturer, PhD., DPPD, Valahia University of Târgovişte, Târgovişte, Dâmbovi a, Romania.

** Lecturer, PhD., DPPD, Valahia University of Târgovişte, Târgovişte, Dâmbovi a, Romania. 
Keywords: bullying, educational climate, educational relationships, socioemotional competences, strategies for preventing and combating bullying.

\section{Rezumat}

Intr-o lume care pare că îşi pierde reperele axiologice, în care conflictele, violen a, agresivitatea sunt prezente la orice palier al ansamblului societal, nici şcoala nu mai reprezintă, pentru copii şi profesori, un mediu sigur şi pozitiv. Bullyingul este un fenomen care s-a insinuat în via a şcolii, având efecte negative asupra sănătă ii fizice şi psihice a copiilor, asupra personalită ii acestora, precum şi asupra eficien ei si calită ii procesului educa ional.

În acest context, prin studiul de fa $\breve{a}$, ne-am propus să investigăm măsura în care profesorii, conştientizând gravitatea ac iunilor subsumate bullyingului, intervin cu promptitudine, adoptând o serie de strategii de prevenire sau/şi de combatere a acestui fenomen. In condi iile în care, la nivelul Uniunii Europene şi nu numai, există o preocupare evidentă pentru prevenirea şi stoparea bullyingului, prin demersul investigativ realizat, în cadrul căruia am inclus un grup de profesori din învă ământul preuniversitar, ne-am propus, de asemenea, să identificăm măsura in care aceştia conştientizează nevoia de implicare, de ac iune imediată, cu scopul de a promova un climat educa ional sigur, de a asigura securitatea fizică şi emo ională a elevilor lor.

Rezultatele anchetei pe bază de chestionar au eviden iat o atitudine proactivă a profesorilor, aceştia conştientizând importan a interven iei lor pentru dezvoltarea unor rela ii armonioase între elevi, pentru formarea/dezvoltarea competen elor socio-emo ionale ale acestora, precum şi pentru diminuarea/stoparea ac iunilor subsumate bullyingului, prin mediere, sanc iuni adecvate, colaborare eficientă cu to i partenerii educa ionali.

Cuvinte-cheie: bullying, climat educa ional, competen e socio-emo ionale, rela ii educa ionale, strategii de prevenire şi combatere a bullyingului.

\section{Introduction}

The disorders of the contemporary world can be found - on a different scale, of course - in the educational environment as well. Aggressiveness, hostility, selfishness, manifested in various forms in the social space, have as correspondent - in school - a phenomenon called bullying. For the last few decades, specialists in education, psychologists and school counselors, but also other specialists from outside the educational space, have been 
worryingly drawing attention to the aggressiveness which is more and more common among children. Whether we refer to verbal or physical aggressiveness, to behavioral problems which affect the way children connect with each other or with their teachers, we find that school has stopped being a safe environment, for both students and teachers.

Many times, even during classes, teachers are forced to manage the interactions between students, to mediate conflicts or even to develop appropriate response reactions to bullying-type behaviors which are directed to himself.

It has already been proven through various studies in the literature that bullying has a negative, even dramatic effect on the mental and physical health of those involved, on their self-image, on their self-esteem, but also on the way we perceive others, on the relations we develop and, because we relate to the school environment, on the academic performances of the students.

In 2016, the Save the children organization conducted a sociological study at national level, entitled Bullying among children, the sample of students investigated being composed of middle and high school students. The recorded data showed that, regarding the threats of physical violence and/ or humiliation, $19 \%$ of the children admitted that they repeatedly humiliated another child at school, $22 \%$ declared they have threatened to strike another child, while $29 \%$ of them admitted that they were threatened with hitting or beating and $24 \%$ have been humiliated or shamed in their classroom. Regarding the witnesses of bullying situations, $84 \%$ of the respondents admitted that they witnessed situations where a child threatened another, while $80 \%$ of them witnessed situations where a child was being humiliated by another child. The results obtained from the items that targeted physical violence and/or destruction of goods are the following: $13 \%$ of children admitted that they happened to destroy another child's goods, $16 \%$ admitted they have repeatedly beaten another child, and $30 \%$ to have repeatedly slightly hit a classmate. At the same time, $32 \%$ of the children stated that they have been pushed or shoved by other children, repeatedly, 39\% said they have been slightly wounded, and $16 \%$ have been repeatedly beaten at school. Also, $73 \%$ of the children participating in the study said that they 
have witnessed a bullying situation in the school environment (Grădinaru, Stănculeanu \& Manole, 2016, p. 52).

In another report, the data resulting from the students' self-assessment are less worrying. Thus, in Romania, $8.7 \%$ of the students have harassed other students. Of those, $1.4 \%$ have frequently displayed this behavior, and $7.3 \%$ sometimes only. The behaviors manifested by the aggressors are: mocking laugh, offensive nicknames, spread of fake rumors, destruction of objects, physical injuries and social isolation. The percentage of boys (11.6\%) that have admitted they have harassed other students - sometimes or frequently - was almost double compared to that of the girls (6\%) that claimed to have manifested the same behavior (Mireştean, 2018, p. 13).

Bullying, with the entire repertoire of forms of manifestations, represents a threat for children's health and their well-being. For this reason, teachers need to be the first to carry out appropriate prevention and intervention actions, being aware that they are responsible for the safety, mental and physical integrity of their students.

\section{Bullying - a descriptive framework}

\subsection{Bullying - definition and forms}

To differentiate bullying from the aggressiveness which is part of the natural process of children development and behavioral disorders, commonly encountered in high school age, the authors of the studies that address the bullying problem, usually use the D. Olweus' proposed criteria. So, in his opinion, "the phenomenon of bullying is thus characterized by the following three criteria: (a) It is aggressive behavior or intentional "harm doing" (b) which is carried out "repeatedly and over time" (c) in an interpersonal relationship characterized by an imbalance of power" (Olweus, 1994, p. 1173).

According to an UNICEF report - Child Well-being in Rich Countries: A comparative overview - "We say a student is being bullied when another student or a group of students say or do nasty and unpleasant things to him 
or her. It is also bullying when a student is teased repeatedly in a way he or she does not like or when he or she is deliberately left out of things. But it is not bullying when two students of about the same strength or power argue or fight. It is also not bullying when a student is teased in a friendly and playful way" (UNICEF, 2013, p. 27).

So, in the school environment, bullying represents a deliberate and repeated form of aggressiveness towards a student or a group of students in the conditions in which between the aggressors and the potential victims there is an asymmetrical relation from the point of view of the power held.

There is a variety of forms of bullying and associated behaviors. Thereby, according to the UNESCO publication entitled Behind the numbers: Ending school violence and bullying, the following forms of bullying are described: Physical bullying assumes repeated aggressions like: hitting, jarring, hurting, pushing, deprivation of personal objects, destruction of personal objects, constraint, etc.

Psychological bullying circumscribes the following behaviors: ignoring, teasing, exclusion from activity/group, gossip, verbal abuse, emotional abuse, etc.

Sexual bullying involves jokes, comments or gests with sexual content. Cyber-bullying refers to the virtual environment and implies behaviors such as: bullying by messages, posts, e-mails, pictures; a website which has denigrating posts regarding one or more students, or which amuses the visitors; posting content (for example, images, photos) without permission; humiliating treatment towards a student/group of students through the mobile phones (texts, calls, video) or online (e-mail, instant messages, social media, chat rooms), etc. (UNESCO, 2019, p. 14)

Only by reflecting to what bullying and its forms of manifestation represent, we can anticipate that this phenomenon can cause major personal and social damages. To be more aware, we'll review some of its consequences, written in the literature, showing, once more, that the immediate teachers' actions for preventing and stopping this phenomenon must be perceived as an urgent step, not only a necessary one. 


\subsection{Bullying consequences}

"Harassing (bullying) can make a child's life an ordeal for weeks, months or even years', shows in a study coordinated by Sorina Irimie - Assessing the well-being of the child in school. 2017-2019 (Irimie, 2019, p.7).

This ordeal "translates", according to the studies (Bond, Carlin, Thomas, Rubin \& Patton, 2001; Craig, 1998; Olweus, 1994, 2013; Rigby, 2003, 2007) in affecting the psychological and physical health, the students' academic performances, but also the educational relations, the educational climate established in the classroom.

Relating to the bullying effects on psychological health, they take the form of depression, anxiety, low self-esteem, emotional disorders, behavioral disorders, predisposition to verbal or physical aggression, the development of some addictions - alcohol, drugs, mental health problems, etc.

In the category of consequences of bullying in terms of physical health, in the literature the following are highlighted: sleep disorders, headaches, stomach pain, palpitations, dizziness, low immunity, impaired brain activity, etc.

On the relational and academic level, it is established that bullying is associated with a negative perception of others, deficient social skills, difficulties in initiating, maintaining and developing relationships with others, changing of the educational climate, well-being and, implicitly, student's academic performances.

In fact, in the study carried out by the organization Save the Children, it is highlighted that "the figures available at international level have determined the appreciation of the phenomenon of bullying, together with the parental education style, as a fundamental risk factor for the mental health of children and adolescents and for optimal development of their potential for academic learning and social function" (Grădinaru, Stănculeanu \& Manole, 2016, p. 9). 


\subsection{Prevention and intervention strategies}

Relating to the toxic effects of bullying on a personal and social level also, we believe that identifying appropriate prevention and intervention strategies should be a priority for all the teachers and for any educational institution. In the European Guide of Anti-Bullying Good Practices (Artinopoulou \& Iro, 2014), in the development of which Romania also participated, are mentioned some measures/actions that have already been adopted/ implemented, of which we mention: The National Anti-violence Strategy, the Plan on Reducing the School Violence Phenomenon (2012 - 2013) and the National Project "Youth against violence" (2011-2013), all representing initiatives of the Ministry of Education, Research, Youth and Sport (MECTS). However, the attempts to build strategies at an educational policy level, to promote actions aimed at preventing and monitoring the bullying in school, cannot lead to visible results unless the teachers themselves are aware and assume these steps, in order to ensure the well-being of the children in school, to ensure the establishment of an optimal educational climate, based on cooperative relationships, of harmonious communication between all the children.

The design and the implementation of effective strategies for prevention and intervention in bullying situations implies a holistic approach of this phenomenon, because its etiology is complex, the factors responsible for its appearance and manifestation are varied: factors related to the family environment, with the child/children environment that become aggressors, factors associated with the school environment and, respectively, individual factors.

Thus, it is necessary that the specific actions of prevention/intervention should concern not only the child, but also his family, his entourage, his teachers and colleagues.

However, the present study focuses only on investigating how teachers are prepared to act for preventing or stopping school bullying. 


\section{Research Questions}

The questions that led our investigative approach were the following:

What strategies for preventing bullying do teachers from pre-university education use?

What strategies for stopping bullying do teachers from pre-university education use?

\section{Purpose of the Study}

Our research aimed to identify to what extent teachers, who are aware of the existence of this phenomenon, put into effect adequate strategies for preventing or intervening in order to avoid or diminish the negative, sometimes even dramatic consequences of bullying.

\section{Research Methods}

In order to make this investigation, we chose to combine the two fundamental types of research - quantitative and qualitative; circumscribed to these types of approach, the methods used were questionnaire and focus group.

The designed and administered questionnaire was a scale type one, with 27 closed answer items; the possible answers were distributed on a five-step Likert scale, from to a very large extent to a very small extent. The scale's items were divided into three main categories: the first aimed to identify the forms of manifestations of bullying in the classroom ( 5 items); the second one traced the consequences of bullying ( 7 items) and the third one focused on the strategies for preventing and intervening/fighting bullying behaviors (15 items).

The sample consisted of 116 teachers, 96 (82\%) females and $20(18 \%)$ males, between the ages of 28 and 57, from pre-university education (from the level of primary school, middle school and high school), from Dâmbovi a county and Prahova county. From 116 teachers, 20 people participated also 
to the focus group discussions. We mention that in the case of the questionnaire, the sampling was simple random, whereas in the case of the focus-group, the sampling was stratified random, taking into account the following criteria: environment (urban/rural), experience (0-5 years, 5-10 years, 10-15 years, 15-20 years, over 20 years in school), degree (no degree, definitive, second didactic degree, first didactic degree), the level of schooling at which the teachers work (primary school, middle school, high school)

The data collected through the questionnaire and the focus group discussion, processed afterwards, led us to a series of findings and interpretations which are to be presented in the following section. We choose to select, from the data collected through questionnaire, only the answers of the subjects to the section of Strategies for preventing and combating bullying, because our article focuses on this aspect. The data obtained in the other two sections of the questionnaire were being used in other scientific articles.

\section{Findings}

This research focuses on presenting the results obtained from the last category of questions of our scale questionnaire, the one that focused on the strategies for preventing and intervening/fighting bullying behavior.

For a better organization and interpretation of the data, we chose to group the items belonging to the above mentioned category into four subdivisions: prevention strategies at the level of classroom/educational climate; prevention strategies that focus on the training/development of the students' emotional competences; intervention strategies applied in communication (with the students' parents, with the school principal, with the psychologist/ school counselor) and intervention strategies - applied in various activities (intervention through mediation, intervention through disciplinary sanctions).

The teachers' answers regarding the items belonging to the first subdivision of strategies for preventing bullying in the classroom/educational climate are summarized in Figure no. 1. 


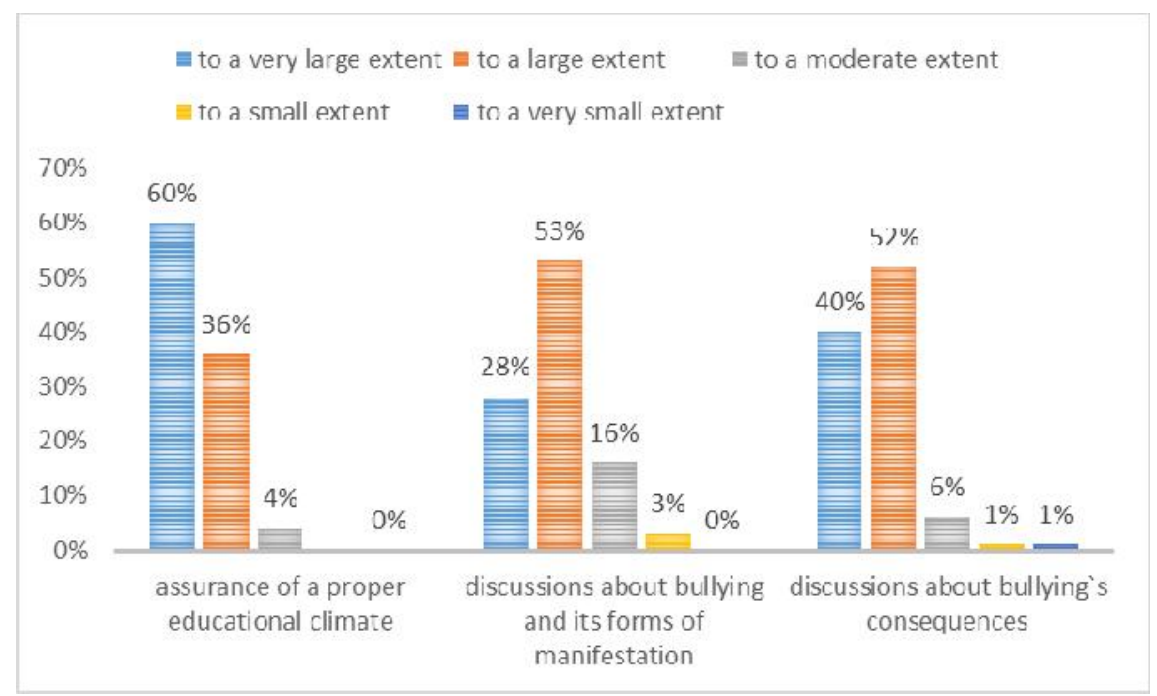

Figure no. 1. Prevention strategies at the level of classroom/educational climate

If we analyze the percentages, we can notice that teachers say they use the ensurance of a proper educational climate to a very large extent as a strategy for preventing bullying in the classroom; this is followed by discussions about the consequences of bullying and discussions about bullying and its forms of manifestation.

Taking into consideration the positioning of the answers, mostly in the high area of the Likert scale, we can conclude that teachers from pre-university education are aware of bullying and its forms of manifestation and adopt adequate measures of preventing bullying in the classroom.

The second subdivision of items refers to the measures of preventing bullying that focus on the training/development of the students' emotional competences. 


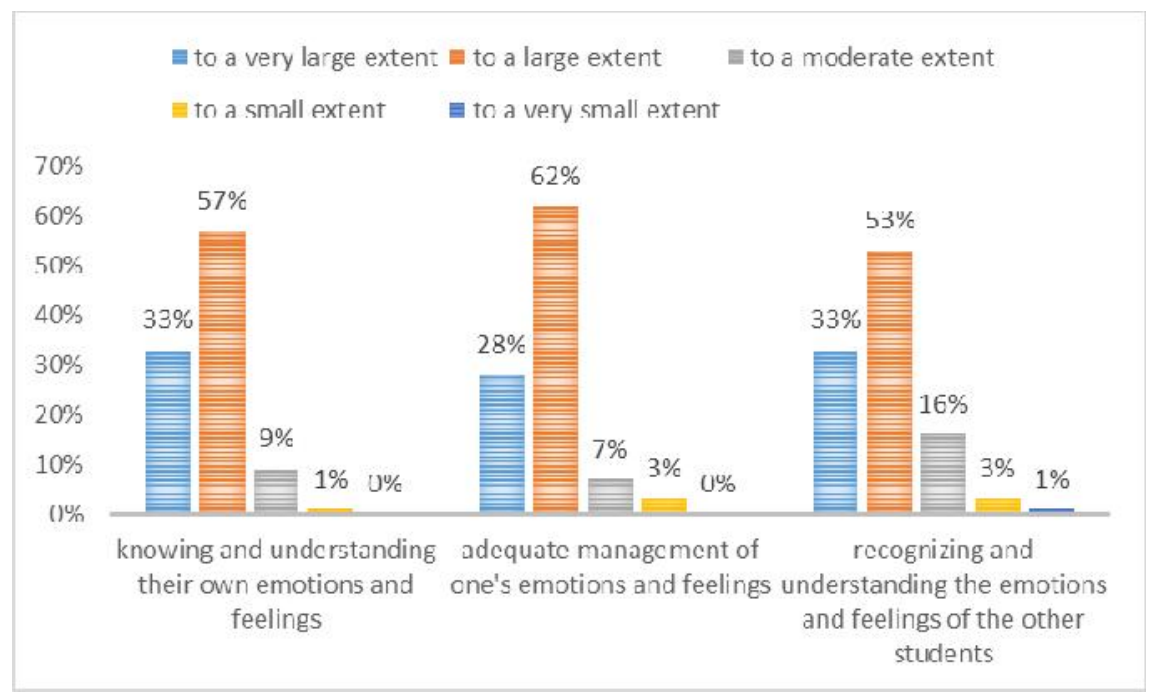

Figure no. 2. Prevention strategies at the level of the students' emotional competences

When questioned about this aspect, teachers from the research sample place all the three dimensions of the training/development of the students' emotional competences above mentioned more or less at the same level on Likert scale (Figure no. 2): knowing and understanding their own emotions and feelings; adequate management of one's emotions and feelings; recognizing and understanding the emotions and feelings of the other students. However, we take note of the respondents' caution which don't choose the highest step from the Likert scale; they rather select an option from the middle of the scale in more than $50 \%$ of the cases $(57 \%, 62 \%$ and $53 \%)$.

The next group of items pinpointed the intervention strategies in order to combat bullying, that are applied in communication: discussions with parents, with the school principal and with the psychologist/school counselor. Figure no. 3 shows the graphic distribution in percentage of the teachers' answers regarding this category of strategies. 


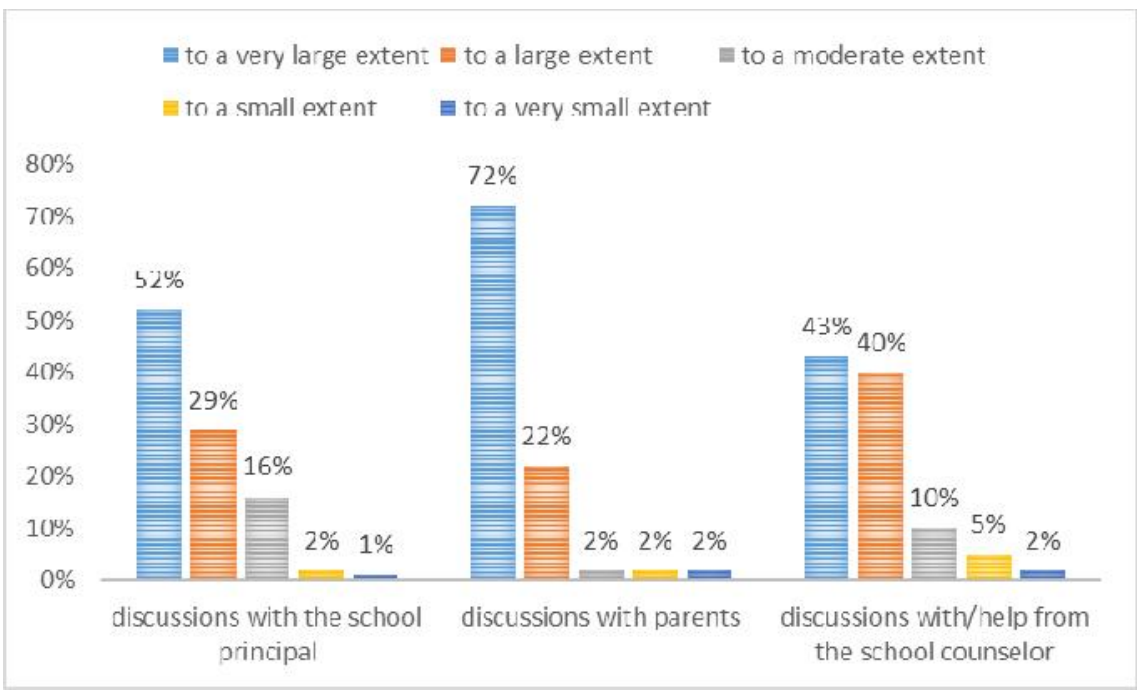

Figure no. 3. Intervention strategies - communication /relationships between parents and school

As we can see in Figure no. 3, teachers declared that they used the discussions with parents to a very large extent (72\%) as a strategy for intervention this option is followed by discussions with the school principal $(52 \%)$ and discussions/requests for help from the school counselor (43\%).

The recorded data from these items lead us to the idea that the respondents are aware of how important the collaborative relationship with the parents really is for solving the problems subsumed to the bullying phenomenon; teachers consider that parents should be immediately informed regarding this sort of behavior and they should also be consulted in order to find the best solutions.

When parents are disconnected from school life, from what happens to their children in the school environment and lack communication with teachers there are disastrous consequences for children, whether they are aggressors, victims or witnesses of bullying.

The items focused on the intervention strategies - applied to the activity level - were: prompt intervention to stop bullying through mediation and application of disciplinary sanctions to the students involved. 


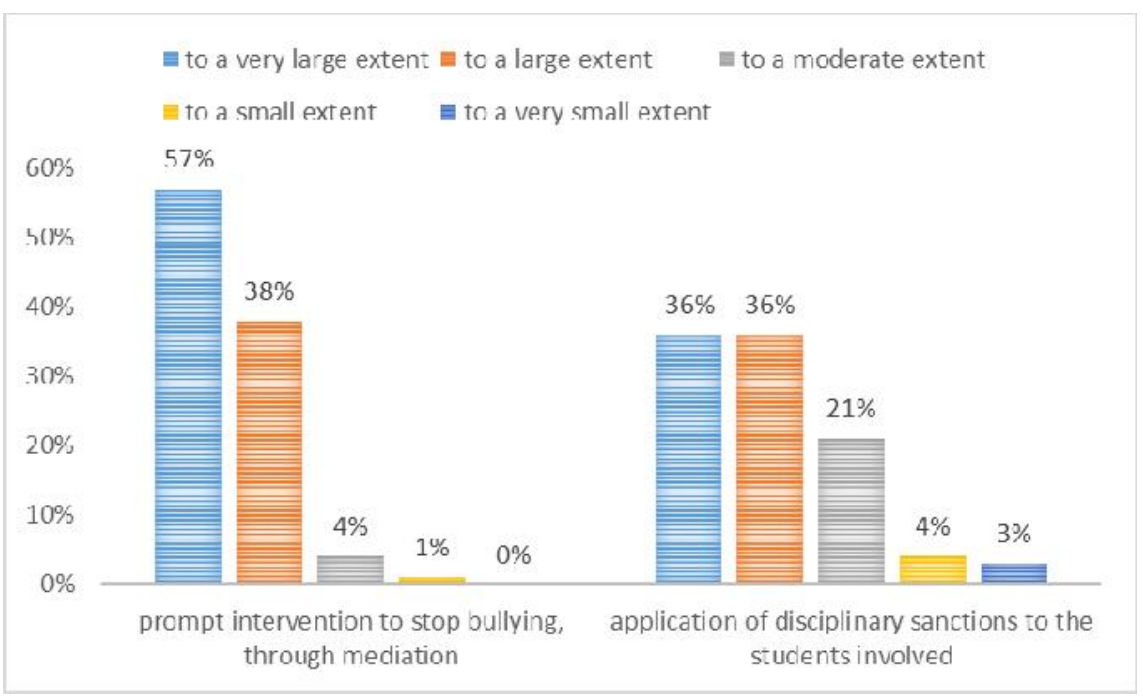

Figure no. 4. Intervention strategies - action level

Questioned teachers declared that prompt intervention through mediation in order to stop bullying was used to a very large extent $(57 \%)$. A considerably smaller percentage of teachers (36\%) asserted that they used disciplinary sanctions to a very large extent as a strategy for intervening as far as bullying behavior is concerned. The answers' distribution outlines the presupposition that teachers tend to intervene in a peaceful way - through mediation - in order to solve the problems circumscribed to bullying; they only resort to restrictive measures such as disciplinary sanctions only after mediation proves to be useless.

The discussions with the teachers in the focus-group sample aimed at clarifying some aspects addressed in the administered questionnaires, of which we mention: ways to ensure a proper educational climate, time allocated to the debate of the complex issue of bullying, strategies for developing emotional competences of students, collaboration with the school counselor to prevent/combat bullying.

By analyzing the results obtained on one of the questions, respectively How do you ensure a proper educational climate at class level? we find that the 
most commonly used terms were: educational relationships, emotional competences and communication. Participating teachers appreciate that by promoting, relationships based on open communication, mutual respect and trust at class level, the aggressive behaviors and implicitly bullying, will be successfully prevented. Also, through capitalizing their own emotional competences, especially empathy, they assure an efficient management of each student's emotionality, so the moments that could degenerate into repeated verbal and physical conflicts or aggression are avoided. Last but not least, the promotion of both vertical communication - teacher-student and horizontal communication - student-student, allows a better interconnection at the level of the student group, which is a premise for identifying common aspects, elements which can play the binder role of the school group, increasing its cohesion.

Regarding the time allocated for the debate on the complex issue of bullying, all participants mentioned that, within the activities included in the school program, those subsumed to Personal Development, Civic Education - for primary school, respectively for Counseling and personal development for middle and high school education represent the framework suitable for the analysis of some aspects specific to the bullying phenomenon. From the answers provided by the teachers participating in the focus-group, it can be seen that they appreciate that, in order to have a greater impact on the students and increase their efficiency, it is necessary that the approach of bullying to be carried out in the context of educational programs launched at the school level, based on various activities like: watching relevant videos/materials, meetings with psychologists, school counselors, doctors, representatives of associations/organizations that act to prevent/combat bullying, common activities teacher-students-parents.

Referring to the strategies for developing students' emotional competences (knowing and understanding their own emotions and feelings; adequate management of one's emotions and feelings; recognizing and understanding the emotions and feelings of the other students), participants in the focusgroup mentioned that these strategies are quite difficult to put into practice, firstly because they do not have sufficient competences in this field. Also, teachers invoke the lack of time needed to create favorable contexts for the development of students' emotional competences. Being asked to exemplify 
concrete situations in which the students' emotional competences can be developed, the teachers mention the hours of Counseling and personal development and Social education (for middle school and high school) and Personal Development (for primary education), hours in which they can organize activities like: games of self-knowledge and teambuilding, role play, debates on relevant topics, analysis of case studies. However, the teachers admitted that those exercises are insufficient to produce sustainable emotional acquisitions.

Another issue discussed within the focus group was the collaboration with the school counselor for reducing/combating bullying. Starting from the data obtained through the questionnaire, which reveals that the discussions with the counselor are placed third in the hierarchy of intervention strategies for combating bullying, after those with parents and the school principal, we wanted to find out the reasons for this hierarchy. Thus, more than half of the participants in the focus group stated that they do not have a school counseling office in their school or they have a counselor who work with students for two or more schools in the same area, so that he cannot give the necessary time to all the cases existing in each school.

\section{Conclusions}

Based on the data obtained in the research, further analyzed and interpreted, we can formulate some general ideas, with conclusive value:

- regarding the strategies for preventing bullying, adopted at the classroom level, the strategy the most used by teachers is the assurance of a proper educational climate;

- regarding the strategies for preventing bullying by training/developing students' emotional competences (knowing and understanding their own emotions and feelings; adequate management of one's emotions and feelings; recognizing and understanding the emotions and feelings of the other students), the research subjects consider these to be important, but they manifest caution in choosing the highest rank on the Likert scale when questioned about the extent to which they are used; this may indicate the lack of sufficient teacher training in the direction of the students' emotional training; 
- the intervention strategies (at the communication level); the most frequent are, according to the answers given by the teachers, the discussions with the parents; the discussions and help requested by the school counselor are placed last in the hierarchy of these strategies, although the school counselor could come up with adequate and scientifically validated solutions to solve the various problems related to bullying; this situation is explained by the fact that not all schools have a counselor or there is a counselor who deals with a large number of students from several schools; - at the action level, the most commonly used strategy is mediation, according to the respondents.

Corroborating this information with those registered within the focus group, but also with those selected from the literature, it is highlighted that bullying is a serious problem at school level, but not always sufficiently well managed and controlled. In this context, we cannot help but wonder if teachers do not wish to present an improved school reality, offering rather desirable answers, to the detriment of some totally sincere ones. One possible reason for such a situation could be precisely the lack or the insufficient development of competences necessary for the adequate bullying management by teachers. As a future research direction, we want to supplement the data of this study with the opinions, the perceptions of the students related to the phenomenon of bullying.

Teachers, counselors and school psychologists must no longer ignore this phenomenon, which tends to become a scourge of the Romanian school. Engaging in appropriate prevention and intervention actions is imperative for all educational actors, as long as we are concerned with our children's health, their mental and physical security and, of course, providing a healthy educational climate. Students can practice an authentic learning, with results that set them up for scholar success only in an environment where are promoted behaviors of mutual support, cooperation, tolerant attitudes and respect towards otherness and values such as equity, right to opinion, solidarity.

\section{Notes}

The authors have an equal contribution to this paper 


\section{References}

- Artinopoulou, V., \& Iro, M. (Eds.). (2014). Ghidul European de Bune Practici Antibullying. Retrieved from http://www.antibullying.eu/sites/default/files/ guide_of_good_practices_ro.pdf

- Bond, L., Carlin, J. B., Thomas, L., Rubin, K., \& Patton, G. (2001). Does bullying cause emotional problems? A prospective study of young teenagers. BMJ, 323(7311), 480-484. https://doi.org/10.1136/bmj.323.7311.480

- Craig, W.M. (1998). The relationship among bullying, victimization, depression, anxiety, and aggression in elementary school children. Personality and Individual Differences, 24(1), 123-130. https://doi.org/10.1016/S0191-8869(97)00145-1

- Grădinaru, C., Stănculeanu, D., \& Manole, M. (2016). Bullying-ul în rândul copiilor. Studiu sociologic la nivel na ional. Organiza ia Salva i Copiii. Retrieved from https://oradenet.salvaticopiii.ro/docs/Bullying_Studiu_sociologic_salvati_ copiii.pdf

- Irimie, S. (Ed.). (2019). Evaluarea stării de bine a copilului în şcoală. 20172019. Ministerul Sănătă ii. Institutul Na ional de Sănătate Publică. Retrieved from http://insp.gov.ro/sites/cnepss/wp-content/uploads/2014/12/Sinteza-starede-bine-in-scoala-2019.pdf

- Mireştean, I.M. (Ed.). (2018). Utilizarea modelului ecologic pentru interven iile de prevenire a violen ei la elevi. Sinteza na ională pentru anul 2018. Ministerul Sănătă ii. Institutul Na ional de Sănătate Publică. Retrieved from http:// insp.gov.ro/sites/cnepss/wp-content/uploads/2014/12/Sinteza-prevenireviolenta-elevi-2019.pdf

- Olweus, D. (1994). Bullying at School: Basic Facts and Effects of a School Based Intervention Program. Journal of Child Psychology and Psychiatry, 35(7), 1171-1190. https://doi.org/10.1111/j.1469-7610.1994.tb01229.x

- Olweus, D. (2013). Bullying at school. What we know and what we can do. Oxford: Blackwell Publishing.

- Rigby, K. (2003). Consequences of Bullying in Schools. The Canadian Journal of Psychiatry, 48(9), 583-590. https://doi.org/10.1177/070674370304800904

- Rigby, K. (2007). Bullying in Schools: and what to do about it. Victoria: ACER Press.

- UNESCO. (2019). Behind the numbers: Ending school violence and bullying. Paris: UNESCO.

- UNICEF Office of Research. (2013). Child Well-being in Rich Countries: A comparative overview, Innocenti Report Card 11. Florence: UNICEF Office of Research. Retrieved from https://www.unicef-irc.org/publications/pdf/ rc11_eng.pdf 
The online version of this article can be found at: http://revped.ise.ro/category/2019-en/

\section{(CC) BY-NC-BA}

This work is licensed under the Creative Commons Attribution-NonCommercial-ShareAlike 4.0 International License.

To view a copy of this license, visit http://creativecommons.org/licenses/by-nc-sa/4.0/ or send a letter to Creative Commons, PO Box 1866, Mountain View, CA 94042, USA.
Versiunea online a acestui articol poate fi găsită la: http://revped.ise.ro/category/2019-ro/

\section{(cc) BX-ne-za}

Această lucrare este licen iată sub Creative Commons Attribution-NonCommercial-ShareAlike 4.0 International License.

Pentru a vedea o copie a acestei licen e, vizita $i$ http://creativecommons.org/licenses/by-nc-sa/4.0/ sau trimite i o scrisoare către Creative Commons, PO Box 1866, Mountain View, CA 94042, SUA. 